\title{
ON THE ISSUE OF IMPROVING THE ACTIVITIES OF THE AVIATION SECURITY SERVICE IN RUSSIA
}

\author{
Alexander V. Sarychev \\ Belgorod Law Institute of the Ministry of Internal Affairs of Russia named after I.D. Putilin, \\ Belgorod, Russian Federation \\ Ivan N. Arkhiptsev \\ Belgorod Law Institute of the Ministry of Internal Affairs of Russia named after I.D. Putilin, \\ Belgorod, Russian Federation \\ Ekaterina A. Karaulova \\ Belgorod Law Institute of the Ministry of Internal Affairs of Russia named after I.D. Putilin, \\ Belgorod, Russian Federation
}

\begin{abstract}
Introduction: Aviation Security Service is an independent system that ensures the safety of air passengers and the airport as a whole. It has been given a free hand recently, namely, with the adoption of Federal Law No. 491-FZ Dated December 31, 2017 “On Amending the Aviation Code of the Russian Federation for ensuring aviation security”. Before the enactment, these functions were fulfilled by the police. In its activities, the police used some technical means necessary to identify the objects prohibited in circulation, but after the transfer of such powers to the Aviation Security Service, there was a process of improving and digitalizing technical devices, which contributed to improving the quality of screening air passengers, baggage and airport facilities. In its activities, the Aviation Security Service uses a highly systematic improved safety technology; a huge range of high-tech devices is used to ensure this service. But despite the improvement of technologies in the inspection system, the broadening of powers of the Aviation Security Service, there are also several shortcomings in its activities. Such are the gaps in the regulatory framework both for the Aviation Security Service itself and for interaction with the territorial Departments of Internal Affairs in transport. In addition, there is poor recruitment of personnel and corruption component in this area. Purpose: the purpose of the study is to analyze the features of aviation security in Russia and develop measures to improve the activities of the Aviation Security Service. Research methods: the methodological framework for the

$\vec{\sim}$ study is made up of the general scientific methods of cognition. To ensure the objectivity of the research, the analyzed ণิ problem is revealed by the authors as a phenomenon using a systematic approach, which allows us to reveal its $\dot{i}$ mechanism in such a way that the theoretical provisions are used with maximum efficiency in practical activities.

Lesearch results and conclusions: the authors highlight the features of the activities of the Aviation Security Service ô in Russia during inspection measures, and also identify the main security problems at the airports.

Key words: security, aviation, airport, Aviation Security Service, police, acts of unlawful interference, warning.

Citation. Sarychev A.V., Arkhiptsev I.N., Karaulova E.A. On the Issue of Improving the Activities of the Aviation Security Service in Russia. Legal Concept = Pravovaya paradigma, 2021, vol. 20, no. 4, pp. $174-183$. (in Russian). DOI: https://doi.org/10.15688/lc.jvolsu.2021.4.24
\end{abstract}

\section{К ВОПРОСУ О СОВЕРШЕНСТВОВАНИИ ДЕЯТЕЛЬНОСТИ СЛУЖБЫ АВИАЦИОННОЙ БЕЗОПАСНОСТИ В РОССИИ}

\section{Александр Викторович Сарычев}

Белгородский юридический институт МВД России им. И.Д. Путилина, г. Белгород, Российская Федерация 


\section{Иван Николаевич Архипцев}

Белгородский юридический институт МВД России им. И.Д. Путилина, г. Белгород, Российская Федерация

\section{Екатерина Алексеевна Караулова}

Белгородский юридический институт МВД России им. И.Д. Путилина, г. Белгород, Российская Федерация

Введение: служба авиационной безопасности (САБ) представляет собой самостоятельную систему, которая обеспечивает безопасность авиапассажиров и аэропорта в целом. Всю широту своих полномочий она получила недавно, а именно с принятием Федерального закона от 31 декабря 2017 г. № 491-Ф3 «О внесении изменений в Воздушный кодекс Российской Федерации в части обеспечения авиационной безопасности». До вступления этого закона данными функциями занималась полиция. В своей деятельности полиция использовала ряд технических средств, необходимых для выявления объектов, запрещенных в обороте, но после передачи таких полномочий службе авиационной безопасности произошел процесс совершенствования и цифровизации технических устройств, что поспособствовало улучшению качества осуществления досмотра авиапассажиров, багажа и объектов аэропорта. В своей деятельности САБ используют высоко систематизированную усовершенствованию технику безопасности, на обеспечении данной службы стоит огромный спектр высокотехнологических устройств. Но, несмотря на совершенствование технологий в досмотровой системе и расширение полномочий САБ, имеет место быть и ряд недостатков в ее деятельности. Таковыми являются, например, пробелы как в нормативной базе самой службы авиационной безопасности, так и по взаимодействию с территориальными ОВД на транспорте. Кроме того, в данной сфере часто встречаются некачественный подбор персонала и коррупционная составляющая. Цель исследования - проанализировать особенности обеспечения авиационной безопасности в России и разработать меры по совершенствованию деятельности службы авиационной безопасности. Методы исследования: методологическую основу данного исследования составляют общенаучные методы познания. С целью обеспечения объективности исследования анализируемая проблема раскрывается нами как явление при использовании системного подхода. Это позволяет раскрыть его механизм таким образом, чтобы теоретические положения с максимальной эффективностью использовались в практической деятельности. Результаты исследования и выводы: авторами выделены особенности деятельности службы авиационной безопасности в России при проведении досмотровых мероприятий, а также выявлены основные проблемы безопасности в аэропортах.

Ключевые слова: безопасность, авиация, аэропорт, служба авиационной безопасности, полиция, акты незаконного вмешательства, предупреждение.

Цитирование. Сарычев А. В., Архипцев И. Н., Караулова Е. А. К вопросу о совершенствовании деятельности службы авиационной безопасности в России // Legal Concept = Правовая парадигма. $-2021 .-$ T. 20, № 4. - C. 174-183. - DOI: https://doi.org/10.15688/lc.jvolsu.2021.4.24

\section{Введение}

Одним из основополагающих элементов осуществления безопасности на воздушном судне является эффективность работы службы авиационной безопасности. В связи с увеличением риска совершения террористических актов, которые проявляются в захвате воздушного судна; проносе, установке и приведении в действие взрывных устройств; захвате заложников и т. д., а также с ухудшением политической и социально-экономической составляющих стран, повышением конфликтных зон, появилась необходимость в совершен- ствовании предполетного досмотра, досмотра груза, самолетов и других авиационных средств.

В связи с тем, что воздушный транспорт является одним из важнейших компонентов нормального функционирования государства, любая попытка выведения из строя данного транспорта приводит к резкому резонансу в обществе. Различные незаконные деяния, связанные с нарушением действия воздушной инфраструктуры, подрывают веру общества в безопасность, а также вносят отрицательный вклад в ухудшение политической и социальной сфер жизни. Все это побуж- 
дает такой орган, как Федеральная авиационная служба РФ, к активному совершенствованию мер, связанных с досмотром как граждан, так и воздушных судов, выполняющих внутренние и международные рейсы.

Анализируя статистические данные о происшествиях на объектах воздушного транспорта, необходимо отметить наибольшую угрозу совершения взрыва.

Так, например, 24 января 2011 г. в зале прилетов международных рейсов московского аэропорта Домодедово террорист-смертник Магомед Евлоев взорвал бомбу мощностью от 5 до 10 кг в тротиловом эквиваленте. На месте погибли 35 человек, впоследствии в больницах скончались еще двое пострадавших, всего ранения получили порядка 170 человек.

31 октября 2015 г. на борту лайнера Airbus321 авиакомпании «Когалымавиа», выполнявшим рейс Шарм-эш-Шейх - Санкт-Петербург, из-за действия взрывного устройства погибло 224 пассажира и члена экипажа самолета [2]. 22 марта 2016 г. в аэропорту города Брюсселя произошло 2 взрыва, произведенные террористами смертниками, в результате чего 14 человек погибли, а 96 получили телесные повреждения различной степени тяжести [5].

Как мы видим из приведенных выше примеров актов незаконного вмешательства, эти угрозы создают необходимость в усилении проведения досмотров всех составляющих аэропорта. Целью досмотра является обнаружение запрещенных объектов и веществ. Для качественного проведения данного мероприятия, сотрудники службы авиационной безопасности (далее - САБ) должны обладать специальными навыками и проходить профессиональную подготовку. В связи с этим следует отметить, что сотрудники САБ допускаются к осуществлению своей непосредственной работы только после того, как пройдут специальную подготовку, проверку знаний и документальное оформление (лицензирование) своей деятельности.

При отборе кандидатов важной составляющей является значимость человеческого фактора, поэтому отбор персонала должен проходить с особой строгостью. Основными критериями отбора являются высокая стрессоустойчивость, а также умение пользоваться специализированными техническими устройствами.
Следующим критерием является непосредственно подготовка высококвалифицированного сотрудника. Так, после принятия на обучение данных лиц, необходимо обучить их специальным навыкам и умениям в данной сфере. Для этого существуют различные приборы с использованием компьютерных технологий. Примерами являются прибор «Студент», который используется для выявления разных предметов в вещах и грузах, и прибор «Курсан» для поиска взрывных устройств.

Данная охранная структура получила всю широту полномочий сравнительно недавно. Ранее функциями осуществления предполетного досмотра, досмотра багажа и ручной клади, а также осуществлением безопасности воздушной инфраструктуры занималась полиция. Так, Федеральным законом от 31 декабря 2017 г. № 491-Ф3 «О внесении изменений в Воздушный кодекс Российской Федерации в части обеспечения авиационной безопасности» была исключена норма, содержащаяся в Федеральном законе от 3 февраля 2014 г. № 15, а также в Федеральном законе от 7 февраля 2011 г. № 3-Ф3 «О полиции», которая предполагала обеспечение полицией авиационную безопасность как на воздушном судне, так и в аэропорту, было отменено положение об участии в осуществлении предполетного досмотра пассажиров, багажа и ручной клади. Согласно новой редакции Воздушного кодекса (далее - ВК РФ) полиция осуществляет свою деятельность в рамках Ф3 «О полиции», а досмотр осуществляет исключительно служба авиационной безопасности. Органы внутренних дел больше не участвуют и в согласовании правил проведения предполетного и послеполетного досмотра, которые теперь принимаются единолично федеральным исполнительным органом, уполномоченным в области транспорта [10]. В связи с этим, как правильно указывают А.А. Разувакин и Н.М. Тюкалова, возникают проблемы взаимодействия правоохранительных органов и представителей авиакомпаний в сфере обеспечения безопасности авиации [4, с. 60].

Однако следует отметить, что законодательство не исключает возможности осуществления данных мер сотрудниками полиции. Так в случае проведения оперативно-розыскных мероприятий, а также в случае наруше- 
ний правил провоза или проноса предметов, запрещенных в обороте, сотрудники полиции имеют право на проведение необходимых мер, предусмотренные нормативными актами.

Необходимо заметить, что принятие Федерального закона, ограничивающего право полиции на осуществление предполетного досмотра, вызвало появление конфликтной ситуации. Так, в случае нарушений пассажирами правил перевозки запрещенных в обороте предметов, создании угрозы жизни и здоровью граждан, путем совершения противоправных деяний, сотрудники авиационной безопасности не имеют полномочий задердживать таких правонарушителей. Необходимо ожидать сотрудников полиции для принятия мер к привлечению к ответственности. Это вызывает некий диссонанс в работе САБ.

Таким образом, следует отметить, что служба авиационной безопасности получила всю широту полномочий сравнительно недавно. Она представляет собой самостоятельную структуру, которая обеспечивает как безопасность пассажиров, экипажа и сотрудников аэропорта, так и безопасное функционирование аэропорта в целом. Работа, связанная с осуществлением досмотра, требует постоянной концентрации, четкого выполнения инструкций и приказов, регламентирующих данную деятельность. Кроме того, немаловажными качествами являются умение принимать быстрое и четкое решение, а также навыки применения специальных средств. Для этого необходимо проводить тщательный отбор. Кандидаты еще на первоначальном этапе должны обладать навыками, связанными с умением преодолевать стрессовые ситуации и т. д. С принятием нового Федерального закона, который внес изменения в ВК РФ, а также в Федеральный закон «О полиции», сотрудники полиции были освобождены от осуществления предполетного досмотра, что вызвало некоторые проблемы в осуществление мер связанные с досмотром.

Особенности деятельности

\section{службы авиационной безопасности при проведении досмотровых мероприятий}

Как известно, целью осуществления предполетного досмотра являются защита жизни и здоровья авиапассажиров, экипажа и объектов аэровокзального комплекса; а также пресечение попытки проноса и перевозки, запрещенных в обороте предметов. Для того чтобы решить эти задачи необходимо использование специальных технических средств.

До вступления в силу Федерального закона от 31 декабря 2017 г. № 491-Ф3 «О внесении изменений в Воздушный кодекс Российской Федерации в части обеспечения авиационной безопасности» досмотром занималась полиция. В своей деятельности они использовали ряд технических средств. Основными являлись стационарные пункты с техническими средствами, содержащие различные рамки стационарного металлоискателя, транспортеры рентгенотелевизионного интроскопа, ручные металлоискатели. С развитием технологий и передачей полномочий в этой сфере службе авиационной безопасности и вневедомственной охране, усовершенствовались старые специальные средства, и появились новые [1, с. 196].

Так, существует ряд технических устройств, которые используются для обнаружения оружия, боеприпасов, взрывчатых веществ, взрывных устройств и иных объектов, представляющих угрозу. Современные рентгеновские приборы позволяют автоматически выделить потенциально опасные зоны и отобразить их на мониторе. После чего происходит регистрация и сохранение данной угрозы на устройстве для дальнейшего проведения неотложных мер. Одним из нововведений в досмотровом оборудование, является создание техники, которая дает возможность получить многоракурсные изображения, что позволяет достаточно полно изучить багаж и ручную кладь авиапассажира. Так, например, в аэропорту Шереметьево имеется система согласования багажа. Она помогает отслеживать движение багажа до контейнера в самолете, а также принимать меры в случае, если пассажир опоздал на рейс и договор авиаперевозки с ним был расторгнут. Кроме этого, в аэропортах используют бесконтактный арочный детектор, который безошибочно определяет в багаже / ручной клади наркотические средства и взрывчатые вещества.

Для обеспечения безопасности аэропортовского комплекса был создан централизо- 
ванный центр диспетчера. Данная система позволяет быстро решать проблемы, связанные с выведением из строя технических устройств, а также используется для улучшения организации основных мероприятий воздушной инфраструктуры. Кроме того, она помогает быстрому взаимодействию служб аэровокзала. Так, на рисунке 1 указаны все службы взаимодействия САБ.

Происходит регулирование парковочных мест автотранспорта, амбаров и стоянок с находящимися воздушными суднами. Для этого создается система прохождения разрешения водителя для въезда и выезда с территории аэропорта (парковки). Для служебного персонала созданы КПП, которые также оснащены техническими средствами для осуществления досмотра как водителя и пассажира, так и самого транспортного средства. Вся территория аэропорта оснащена пожарно-охранной сигнализацией и периметральным освещением. Все технические средства, которые стоят на обеспечении службы авиационной охраны прошли необходимые эксперименты и были допущены Роспотребнадзором, а также имеют соответствующие сертификаты соответствия. Служба авиационной безопасности использует весь спектр технических средств. Так, перед посадкой на самолет осуществляются досмотровые мероприятия воздушного судна и багажного отделения. Проводится досмотровый контроль бортовых за- пасов (продуктов питания, буфетно-кухонного оборудования, а также товаров бортовой продажи).

Кроме этого, существуют следующие разновидности специальных технических устройств, представленные на рисунке 2 .

Качеству досмотровой системы ничего не должно мешать. Так, например, в результате неэффективного досмотра в 2011 г. в аэропорте Сургута произошел пожар. В хвостовом отделе самолета ТУ-154 были обнаружены следы взрывчатого устройства, которое было заложено авиапассажиром. Это свидетельствует о том, что необходимо исключить попадание таких предметов, которые приводят к выведению из строя воздушных судов, а также наносят урон жизни и здоровью гражданам. Во всех аэропортах установлен повышенный режим безопасности. Так, например, к проносу и провозу запрещены: колющие режущие предметы, в ручной клади запрещено провозить емкости, превышающие 100 мл, в полном запрете находятся жидкости.

Отсутствие оружия у сотрудников САБ делает невозможной (или затруднительной и опасной) реализацию ими прав, предусмотренных в п. 3 ст. 84 ВК РФ, таких как: 1) задержание для передачи правоохранительным органам лиц, нарушивших требования авиационной безопасности; 2) применение мер в соответствии с законодательством Российской Федерации в случаях, если жизни или здоро-

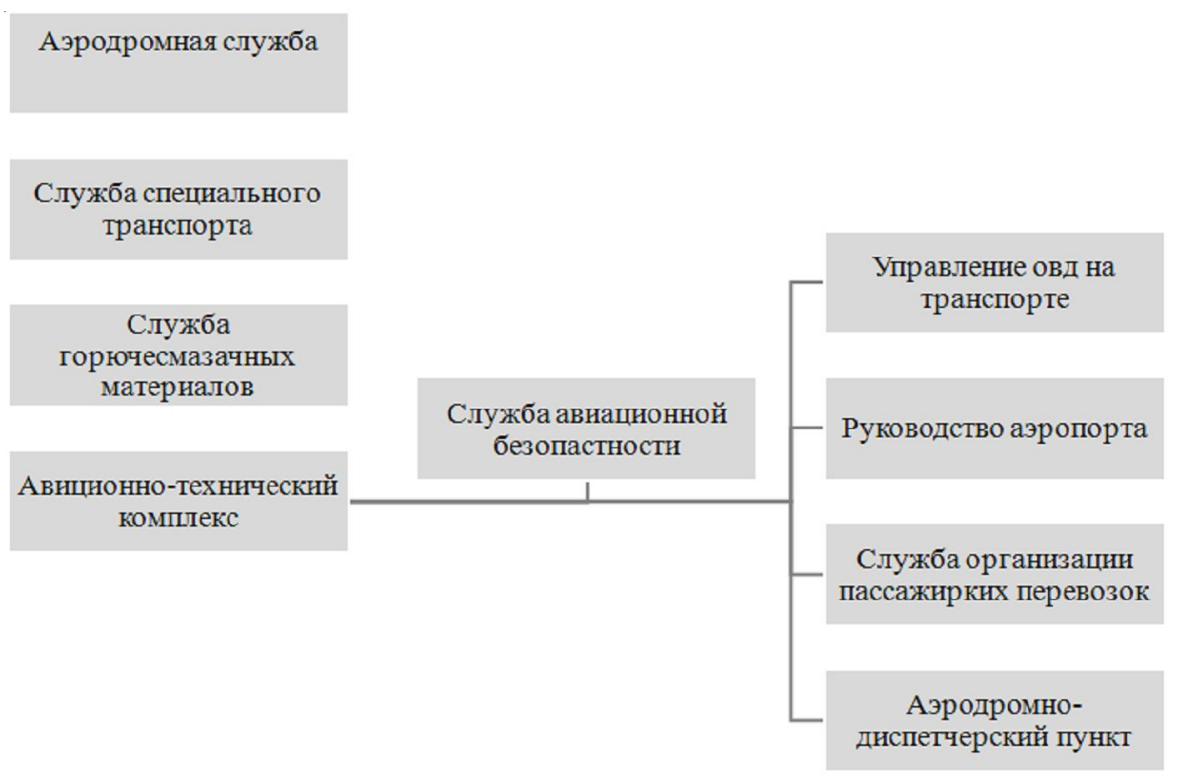

Рис. 1. Службы взаимодействия САБ 
вью пассажиров, членов экипажа воздушного судна или других граждан угрожает опасность. Данная норма является оспоримой. Так, 26 ноября 2018 г. Арбитражный суд города Москвы своим решением удовлетворил заявление ПАО «Аэрофлот - российские авиалинии» о признании частично недействительным предписания, выданного по результатам проверки авиакомпании Управлением государственного авиационного надзора и надзора за обеспечением транспортной безопасности по Центральному федеральному округу (далее - Управление) Федеральной службы по надзору в сфере транспорта (далее - Ространснадзор). Авиакомпания оспорила пункт предписания, содержащий требование о вооружении сотрудников службы авиационной безопасности «Аэрофлота» (дело А41-72460/2018). В период с 3 по 25 мая 2018 г. Управлением была проведена плановая проверка в отношении авиакомпании для оценки ее деятельности на соответствие законодательству Российской Федерации о гражданской авиации и международным договорам Российской Федерации в области гражданской авиации. В ходе проверки было выявлено нарушение п. 5 Федеральных авиационных правил «Тре- бования авиационной безопасности к аэродромам», утвержденных Приказом Министерства транспорта Российской Федерации от 28 ноября 2005 г. № 142 (ФАП-142), а именно: сотрудники САБ авиакомпании не были оснащены служебным оружием и специальными средствами в соответствии с законодательством Российской Федерации. Требование об устранении данного нарушения было включено в предписание от 25 мая 2018 г., выданное по результатам проверки.

В судебном заседании авиакомпания отстаивала позицию о незаконности и неисполнимости данного требования. Основным доводом являлось то, что САБ авиакомпании не относится к субъектам, перечисленным в Федеральном законе от 13 декабря 1996 г. № 150-Ф3 «Об оружии» («Закон об оружии»). Кроме этого, постановление о привлечении «Аэрофлота» к административной ответственности за указанное нарушение было отменено вышестоящим органом Ространснадзора. Суд, установил, что, с учетом изменений, внесенных в ст. 83 ВК РФ, авиакомпания не является юридическим лицом с особыми уставными задачами и, следовательно, не входит в перечень субъектов, имеющих право на приобретение оружия.

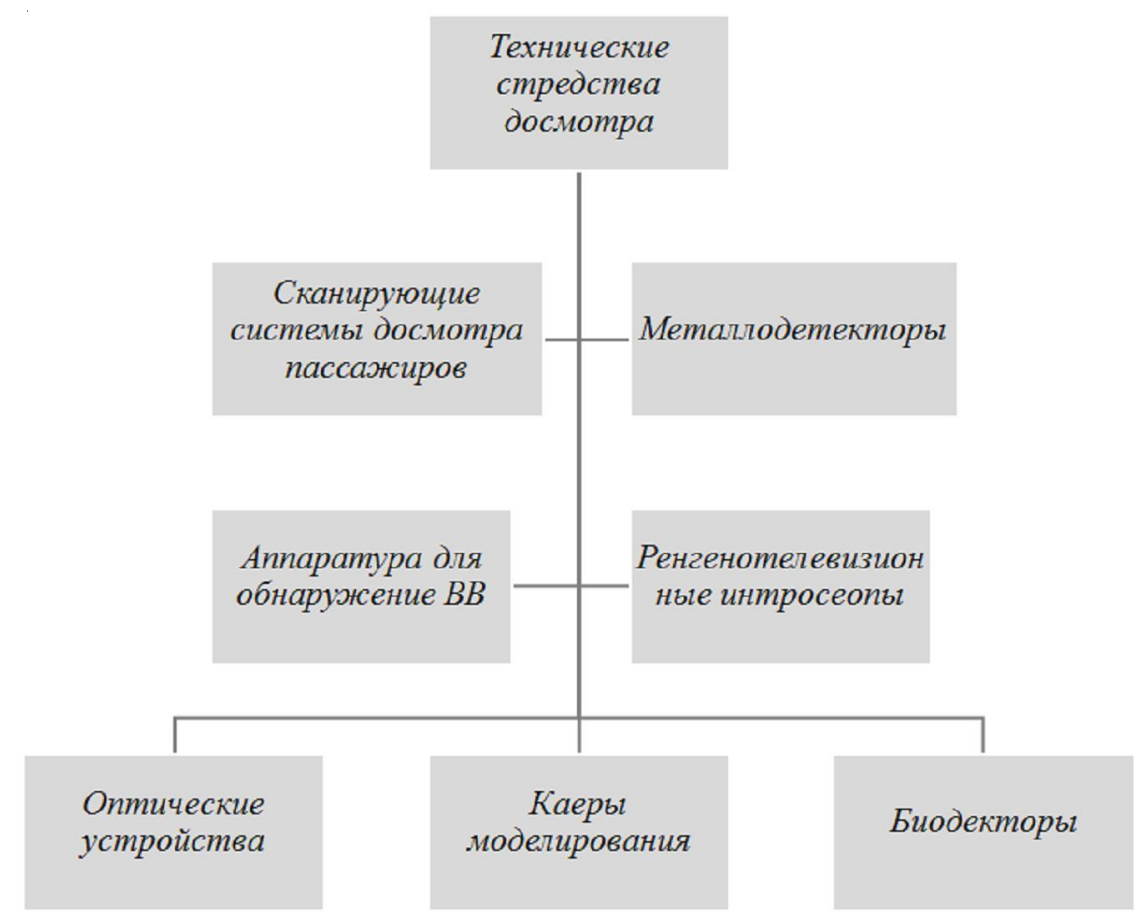

Рис. 2. Виды специальных технических устройств, применяемых в аэропортах 
В результате разрешения данного дела, выяснилось, что законодательство имеет пробелы. Данная компания была освобождена от ответственности, но вопрос об обязанности использования огнестрельного оружия службами авиационной безопасности остался в подвешенном состоянии [7].

Подводя итог вышесказанному, хотелось бы отметить, что до момента вступления в силу Федерального закона от 31 декабря 2017 г. № 491-Ф3 «О внесении изменений в Воздушный кодекс Российской Федерации в части обеспечения авиационной безопасности» безопасностью на аэровокзалах занималась полиция. В своей деятельности она использовала ряд технических средств, необходимых для выявления объектов, запрещенных в обороте. Но после передачи таких полномочий службе авиационной безопасности произошел процесс совершенствования и цифровизации технических устройств, что поспособствовало улучшению качества осуществления досмотра авиапассажиров, багажа и объектов аэропорта. В своей деятельности САБ использует высокосистематизированную усовершенствованную технику безопасности. На обеспечении данной службы стоит огромный спектр высокотехнологических устройств. Несмотря на все это, имеют место быть попытки проноса и провоза взрывчатых веществ, взрывных устройств, наркотических средств и т. д. Причинами являются некачественное соблюдение инструкций по применению технических средств и присутствие человеческого фактора. Еще одной острой проблемой стоит несовершенство в законодательной базе данной службы.

\section{Проблемы обеспечения безопасности в аэропортах}

Рассмотрев высокую оснащенность воздушной инфраструктуры, можно сказать, что, при выполнении четко предложенных инструкций, безопасность аэропорта не будет нарушена. Но, несмотря на все вышеуказанные преимущества технических устройств, систем охранно-пожарной сигнализации и других средств обеспечения безопасности, существует ряд проблем в данной системе.

Так, зачастую, при подборе персонала уполномоченные должностные лица недоста- точно серьезно подходят к данному вопросу. Кроме того, имеет место быть коррупционная составляющая, проявляющаяся в покупке дипломов, сертификатов и поступлении на работу. К сожалению, руководители недостаточно ясно понимают последствия таких нарушений. Так, например, в результате некачественного отбора, на работу может поступить лицо, которое не обладает навыками профайлинга, психологически не устойчиво и некомпетентно в своей речи. Мы солидарны с мнением А.Г. Тетерюка и П.В. Иванова, которые вполне обоснованно считают, что «осуществление эффективной антикоррупционной политики возможно не только путем совершенствования законодательной системы, но и путем осуществления оптимального информационного освещения деятельности по противодействию коррупции, направленного на повышение общественной значимости результатов борьбы с коррупцией» [8, с. 77].

В обязанности сотрудника полиции на транспорте входит как охрана объектов и патрулирование прилегающей территории, так и оперативное реагирование на сообщения САБ о совершении или возможности совершения противоправных действий. САБ и служба вневедомственной охраны, которым были переданы основные полномочия, должны взаимодействовать с сотрудниками полиции. Последним необходимо предоставить полномочия в проведении определенных мероприятий в системе топливно-энергетического комплекca, а также предоставить возможность изучения инфраструктуры аэропорта. Кроме этого, необходимо уделять внимание предупредительным мероприятиям.

Негативно сказывается недостаточность норм в законодательной базе по взаимодействию САБ с полиций. Имеется ряд противоречий, которые наносят урон аэропорту и системе безопасности в целом. Из-за таких проблем полиция и служба авиационной безопасности не могут в полом объеме осуществлять свои полномочия, так как один нормативный акт их предоставляет, а другой, наоборот, ограничивает.

Недостатки нормативно-правовой базы, а также отсутствие достаточного количества научных исследований, направленных на решение проблем организации взаимодействия 
в сфере транспортной безопасности, приводят к существенным затруднениям в организации борьбы с преступностью, которые не могут быть устранены без комплексного, системного подхода к существующей проблеме. Необходимость взаимодействия в сфере авиационной безопасности между транспортными и территориальными органами внутренних дел, а также транспортными предприятиями обусловлена также тем, что для данных структур характерны общие цели, задачи, некоторые функции, применяемые формы и методы работы в направлении обеспечения общественной безопасности, борьбы с терроризмом, незаконным оборотом наркотиков и т. д.

Для осуществления безопасности авиапассажиров, аэропорта и их структурных подразделений необходимо использовать опыт зарубежных стран, например, США и Израиля, которые основывают деятельность на принципе единоначалия и используют современные способы и средства обеспечения авиационной безопасности в аэропортах [6, c. 69-70]. Однако на практике в нашей системе это будет сделать сложно, так как имеет место быть структурный характер. Участие в обеспечении безопасности в нашей стране принимают как структурные подразделения хозяйствующего субъекта, так и органы, относящиеся к правоохранительной системе. Деятельность каждого субъекта регулируют отдельные нормативные акты, а их взаимодействие почти нигде не закреплено что вызывает еще одну проблему эффективности обеспечения безопасности [3, с. 67]. Кроме того, полагаем, что необходимо расширение сотрудничества в области авиационной безопасности со всеми заинтересованными государствами и международными организациями. В частности, по нашему мнению, следует активизировать работу в данном направлении с государствами, входящими в Шанхайскую организацию сотрудничества (далее - ШОС), где приоритетной задачей в транспортной сфере является создание благоприятных условий для развития устойчивого транспортного сообщения, обеспечивающего потребности развития экономического сотрудничества стран ШОС [9, c. 301-302].

\section{Выводы}

Подводя итог изложенному, следует отметить, что, несмотря на совершенствование технологий в досмотровой системе и расширение полномочий САБ, в этой сфере, к сожалению, присутствует ряд недостатков. Таковыми являются пробелы как в нормативной базе самой службы авиационной безопасности, так и по взаимодействию с территориальными ОВД на транспорте. Кроме того, некачественный подбор персонала и коррупционная составляющая приводят к повышению риска неэффективности осуществления авиационной безопасности. Для эффективности обеспечения безопасности требуется четкое определение задач каждого субъекта авиационной безопасности, ответственности каждой организации за порученную часть деятельности, определение сфер и методов их взаимодействия. Необходимая и успешно функционирующая система безопасности в сфере гражданской авиации может быть создана только тогда, когда между субъектами будут устранены все противоречия и конфликты интересов, что, в свою очередь, потребует устранения пробелов в законодательстве и адекватных мер организационного характера.

\section{СПИСОК ЛИТЕРАТУРЫ}

1. Ионов, В. В. Многопараметрическая оценка деятельности операторов интроскопов / В. В. Ионов, В. В. Курчавов // Мир транспорта. - 2014. - № 2 (51). C. 194-201.

2. Катастрофа российского самолета Airbus А 321 «Когалымавиа» в Египте. - Электрон. текстовые дан. - Режим доступа: https://ria.ru/20201031/ krushenie-1582146390.html (дата обращения 01.08.2021). - Загл. с экрана.

3. Краснов, С. И. Разработка критериев качества авиационной безопасности на основе квадратичной зависимости ущерба от отклонения параметров системы / С. И. Краснов, А. М. Лебедев // Научный вестник Московского государственного технического университета гражданской авиации. -2018 . - № 174. - С. 66-68.

4. Разувакин, А. А. Проблемы взаимодействия органов внутренних дел с иными субъектами в области обеспечения авиационной безопасности / А. А. Разувакин, Н. М. Тюкалова // Административное право и процесс. - 2018. - № 5. - С. 60-67. 
5. Серия терактов в Брюсселе 22 марта 2016 года. - Электрон. текстовые дан. - Режим доступа: https://ria.ru/20210322/bryussel-1601974245.html (дата обращения: 01.08.2021). - Загл. с экрана.

6. Столбина, Л. В. Отдельные аспекты обеспечения авиационной безопасности: международный опыт / Л. В. Столбина, О. В. Панфилова, Н. В. Быхтина // Проблемы правоохранительной деятельности. - 2020. - № 1 (39). - С. 66-72.

7. Суд признал неисполнимым требование об оснащении службы авиационной безопасности оружием. Правильно ли суд истолковал закон? Электрон. текстовые дан. - Режим доступа: https:// avialaw.blog/blog/sudebnaya-praktika/sud-priznaltrebovanie-ob-osnashchenii-sluzhby-aviacionnoybezopasnosti (дата обращения: 12.08.2021). - Загл. с экрана.

8. Тетерюк, А. Г. Отдельные аспекты реализации принципов противодействия коррупционной преступности в деятельности территориальных органов МВД России на транспорте / А. Г. Тетерюк, П. В. Иванов // Проблемы правоохранительной деятельности. -2018. - № 1. - С. 77-82.

9. Транспортная безопасность : учебник / А. Н. Александров [и др.] ; под ред. И. Ф. Амельчакова. - Белгород : [s. n.], 2017. - 325 c.

10. Федеральный закон от 31 декабря 2017 г. № 491-Ф3 «О внесении изменений в Воздушный кодекс Российской Федерации в части обеспечения авиационной безопасности» // Собрание законодательства РФ. - 2018. - № 1 (ч. І). - Ст. 75.

\section{REFERENCES}

1. Ionov V.V., Kurchavov V.V. Mnogoparametricheskaia otsenka deyatel'nosti operatorov introskopov [Multiparametric Evaluation of the Activity of Introscope Operators]. Mir transporta [World of Transport], 2014, no. 2 (51), pp. 194-201.

2. Katastrofa rossiiskogo samoleta Airbus A321 «Kogalymavia»v Egipte [The Crash of the Russian Airbus A321 "Kogalymavia" Plane in Egypt]. URL: https://ria.ru/20201031/krushenie-1582146390.html (accessed 1 August 2021).

3. Krasnov S.I., Lebedev A.M. Razrabotka kriteriev kachestva aviatsionnoi bezopasnosti na osnove kvadratichnoi zavisimosti ushcherba ot otkloneniia parametrov sistemy [Development of Aviation Safety Quality Criteria Based on the Quadratic Dependence of Damage on the Deviation of System Parameters]. Nauchnyi vestnik MGTU GA
[Scientific Bulletin of MSTU GA], 2018, no. 174, pp. 66-68.

4. Razuvakin A.A., Tiukalova N.M. Problemy vzaimodeistviia organov vnutrennikh del s inymi subyektami v oblasti obespecheniya aviatsionnoi bezopasnosti [Problems of Interaction of Internal Affairs Bodies with Other Subjects in the Field of Aviation Security]. Administrativnoe pravo $i$ protsess [Administrative Law and Process], 2018, no. 5, pp. 60-67.

5. Seriia teraktov v Briussele 22 marta 2016 goda [A Series of Terrorist Attacks in Brussels on March 22, 2016]. URL: https://ria.ru/20210322/ bryussel-1601974245.html (accessed 1 August 2021).

6. Stolbina L.V., Panfilova O.V., Bykhtina N.V. Otdelnye aspekty obespecheniia aviatsionnoi bezopasnosti: mezhdunarodnyi opyt [Certain Aspects of Aviation Security: International Experience]. Problemy pravookhranitelnoj deiatel'nosti [Law Enforcement Problems], 2020, no. 1 (39), pp. 66-72.

7. Sud priznal neispolnimym trebovanie ob osnashchenii sluzhby aviatsionnoi bezopasnosti oruzhiem. Pravil'no li sud istolkoval zakon? [The Court Found the Requirement to Equip the Aviation Security Service with Weapons Unenforceable. Did the Court Interpret the Law Correctly?]. URL: https:// avialaw.blog/blog/sudebnaya-praktika/sud-priznaltrebovanie-ob-osnashchenii-sluzhby-aviacionnoybezopasnosti (accessed 12 August 2021).

8. Teteriuk A.G., Ivanov P.V. Otdel'nye aspekty realizatsii printsipov protivodeistviya korruptsionnoj prestupnosti $\mathrm{v}$ deiatel'nosti territorial'nykh organov MVD Rossii na transporte [Some Aspects of the Implementation of the Principles of Combating Corruption Crime in the Activities of the Territorial Bodies of the Ministry of Internal Affairs of Russia in Transport]. Problemy pravookhranitel'noj deiatel'nosti [Law Enforcement Problems], 2018, no. 1, pp. 77-82.

9. Aleksandrov A.N. et al. Transportnaia bezopasnost: uchebnik [Transport Security. Textbook]. Belgorod, s.n., 2017.325 p.

10. Federal'nyj zakon ot 31 dekabrya $2017 \mathrm{~g}$. № 491-FZ «O vnesenii izmenenij v Vozdushnyj kodeks Rossiiskoj Federatsii v chasti obespecheniya aviatsionnoj bezopasnosti» [Federal Law No. 491FZ Dated December 31, 2017 “On Amendments to the Air Code of the Russian Federation in Terms of Ensuring Aviation Security"]. Sobranie zakonodatel'stva RF [Collection of Legislation of the Russian Federation], 2018, no. 1, (part I), art. 75. 
А.В. Сарычев, И.Н. Архипцев, Е.А. Караулова. К вопросу о совершенствовании деятельности САБ в России

\section{Information About the Authors}

Alexander V. Sarychev, Lecturer, Department of Tactical and Special Training, Belgorod Law Institute of the Ministry of Internal Affairs of Russia named after I.D. Putilin, Gorkogo St, 71, 308024 Belgorod, Russian Federation,w0773@yandex.ru, https://orcid.org/0000-0002-2115-3191

Ivan N. Arkhiptsev, Candidate of Sciences (Jurisprudence), Associate Professor, Department of Criminal Law Disciplines, Belgorod Law Institute of the Ministry of Internal Affairs of Russia named after I.D. Putilin, Gorkogo St, 71, 308024 Belgorod, Russian Federation, ArhiptsevIN@yandex.ru, https://orcid.org/0000-0003-2307-2712

Ekaterina A. Karaulova, Cadet, Faculty of Law Enforcement Activities, Belgorod Law Institute of the Ministry of Internal Affairs of Russia named after I.D. Putilin, Gorkogo St, 71, 308024 Belgorod, Russian Federation, karaulova.yekaterina@list.ru, https://orcid.org/0000-0003-4963-341

\section{Информация об авторах}

Александр Викторович Сарычев, преподаватель кафедры тактико-специальной подготовки, Белгородский юридический институт МВД России им. И.Д. Путилина, ул. Горького, 71, 308024 г. Белгород, Российская Федерация, w0773@yandex.ru, https://orcid.org/0000-0002-2115-3191

Иван Николаевич Архипцев, кандидат юридических наук, доцент кафедры уголовно-правовых дисциплин, Белгородский юридический институт МВД России им. И.Д. Путилина, ул. Горького, 71, 308024 г. Белгород, Российская Федерация, ArhiptsevIN@yandex.ru, https://orcid.org/0000-0003-2307-2712

Екатерина Алексеевна Караулова, курсант факультета правоохранительной деятельности, Белгородский юридический институт МВД России им. И.Д. Путилина, ул. Горького, 71, 308024 г. Белгород, Российская Федерация, karaulova.yekaterina@list.ru, https://orcid.org/0000-0003-4963-341 